\title{
INDEX OF ABSTRACTS SA HEART CONGRESS 2012
}

Pump dysfunction in hypertensive hypertrophy: Impact of severity of blood pressure elevation in patients of African ancestry

Haroon-ur-Rasheed Abbasi, Elena Libhaber, Gavin Norton, Angela Woodiwiss and Mohammed R. Essop

Clinical and echocardiographic follow-up of the isolated left ventricular non-compaction (ILVNC) cohort at Chris Hani Baragwanath Hospital

Francois Botha, Ferande Peters and Mohammed R. Essop

First Melody ${ }^{\circledR}$ valve implantation in Africa

D.G. Buys and S.C. Brown

Untreated aortic stenosis (AS): guidelines for a tertiary setting

Malcolm Dalrymple-Hay, lan Cox, Sam Melhuish, Tania Riches and Clinton Lloyd

Anomalous origin of the right pulmonary artery from the aorta:

case reports and discussion

H. Dama

Protean manifestations of cardiac hydatidosis

Riaz Suleman Dawood, Ahmed R. Essop, Robert W. Girdwood, Martin J. Sussman and Mohammed R. Essop

Defensive coping and subclinical vascular disease risk - associations with autonomic exhaustion in Africans and Caucasians: the sympathetic activity and ambulatory blood pressure in Africans (SABPA) study

Andrea de Kock, Leoné Malan, Mark Hamer and N.T. Malan

Glucose and insulin: emerging metabolic therapy against acute heart failure (AHF)

Gaurang Deshpande, Sandrine Lecour and Lionel H. Opie

Williams-Beuren syndrome and Ebstein's anomaly variant: a rare association

Adele Dippenaar, Lungile Pepeta and Samina Mahmud Yakoob

Sutureless aortic valve replacement: catheter-based transapical versus direct transaortic implantation Mirko Doss

Review of truncus arteriosus cases seen at Chris Hani Baragwanath Academic Hospital:

a "vanishing syndrome"

G. Dumani, B. Fourie, P.A. Adams and A.M. Cilliers 
The road to a Fontan and beyond - often a bumpy one: a complicated case of tricuspid atresia with a lot of diagnostic and treatment dilemmas

B. Fourie, A.M. Cilliers, P.E. Adams and G.C. Dumani

The effects of acute ethanolamine administration on isoprenaline-induced myocardial infarction in adult Wistar rats

Christie Garson, Asfree Gwanyanya, Kishor Bugarith and Roisin Kelly-Laubscher

The effects of magnesium administration on isoprenaline-induced acute myocardial infarction in adult Wistar rats

Christie Garson, Roisin Kelly-Laubscher, Kishor Bugarith and Asfree Gwanyanya

Overcoming the limitations of current echocardiographic criteria used in the diagnosis of subclinical rheumatic heart disease

Philip G. Herbst, Zaheera Cassimjee, Alfonso J.K. Pecoraro and Anton F. Doubell

Cardioprotective and anti-hypertensive effects of Prosopus glandulosa in a rat model of pre-diabetes Barbara Huisamen, Cindy George, Daneel Dietrich and Amanda Lochner

Racial variability in telomere length and risk of coronary artery disease

Sajidah Khan, Anil Chuturgoon, Devapragasen Moodley and Alisa Phulukdaree

Feline hypertrophic cardiomyopathy associated with the A31P mutation in MYBPC3, is caused by production of mutated protein $\mathrm{C}$ with reduced affinity between the MyBP-C $\mathrm{COC} 1$ domain and actin Craig Kinnear, Mia Godiksen,Tina Nielsen, Peter Høirup, Sara Granström, Inga A. Laursen, Jørgen Koch,

William J. McKenna and Michael Christiansen

Two week proanthocyanidin treatment prevents heart failure in a rat model

Maritza Kruger, Sandrine Lecour and Neil Davies

Role of Toll-like receptor 4 in melatonin-induced cardioprotection

K.T. Lamont, L.H. Opie and S. Lecour

Impact of inappropriate versus absolute or indexed left ventricular mass on on-treatment changes and community variations in ejection fraction

Carlos David Libhaber, Angela J. Woodiwiss, Muzi J. Maseko, Olebogeng H.I. Majane, Aletta Esterhuyse,

Richard Brooksbank, Elena Libhaber, Pinhas Sareli and Gavin R. Norton

Potential mechanisms that account for obesity-related decreases in left ventricular diastolic function

Carlos David Libhaber, Gavin R. Norton, Olebogeng H.I. Majane, Muzi J. Maseko, Elena N. Libhaber,

Mohammed R. Essop, Pinhas Sareli and Angela J. Woodiwiss 
Improved survival and quality of life after TAVI

Clinton Lloyd, lan Cox, Rashmi Birla, Sam Melhuish, Tania Riches and Malcolm Dalrymple-Hay

Isolated left ventricular non-compaction (ILVNC): the Chris Hani Baragwanath experience

Nirvarthi Maharaj, Ferande Peters, Farouk Mamdoo, Claudia dos Santos, Hiral Matioda, Elena Libhaber and

Mohammed R. Essop

Left ventricular twist abnormalities in isolated left ventricular non-compaction (IIVNC)

Nirvarthi Maharaj, Ferande Peters, Elena Libhaber, Claudia dos Santos, Hiral Matioda and Mohammed R. Essop

Twist mechanics in African hypertension patients with systolic dysfunction: an analysis using speckle tracking echocardiography

Nirvarthi Maharaj, Ferande Peters, Elena Libhaber and Mohammed R. Essop

Defensive active coping (AC) facilitates time-domain HRV and sub-clinical vascular disease:

the sympathetic activity and ambulatory blood pressure in Africans (SABPA) study

Leoné Malan, Mark Hamer, Markus Schlaich, Gavin Lambert, Manja Reimann, Nancy Frasure-Smith, Lisa Uys,

Andrea de Kock and Nico Malan

The utility of transoesophageal echocardiography in young stroke patients: insights from TORCH

Farouk Mamdoo, Ferande Peters, Anupa Patel, Hiral Matioda, Samantha Govender and Mohammed R. Essop

Coronary artery disease prevalence amongst patients undergoing valve replacement surgery

Ruchika Meel, Ahmed R. Essop, Anthony Becker, Chris Zambakides, Anthony Yip, Richard Nethononda and

Mohammed R. Essop

Cardiological family screening in isolated left ventricular non-compaction (ILVNC)

Michael Thamaga Mogogane, Ferande Peters, Claudia dos Santos, Hiral Matioda, Richard Nethononda and Rafique Essop

Mortality associated with infective endocarditis (IE)

Jameel Moosa, Ngoba Tsabedze, Ahmed Vachiat, Rohan Ramjee, Thomas Kalk, Keir McCutcheon, Lance Mkhwanazi, Riaz

Garda and Pravin Manga

Invasive haemodynamic evaluation of category 1 pulmonary arterial hypertension (PAH)

Muhammad Zaid Moosa, Paul Williams, Ahmed R. Essop and Mohammed R. Essop

The distribution of conventional pulsed wave-tissue Doppler imaging measurements of the right ventricle by age and sex in a healthy Black South African population

Muhammad Zaid Moosa, Ferande Peters, Nirthi Maharaj and Mohammed R. Essop

Non-ST elevation myocardial infarction (NSTEMI) in 3 hospital settings in South Africa.

Does level of care influence management and outcome? A retrospective cohort study

J. Moses, A.F. Doubell, P.G. Herbst, K.J.C. Klusmann and H.S.V.H. Weich 
The role of novel protein-protein interactions in the function and mechanism of the sarcomeric protein, myosin binding protein $\mathrm{H}$ (MyBPH)

Jacoba Martina Mouton, Johanna C. Moolman-Smook and Craig J. Kinnear

Assessing the effect of a hypertrophic cardiomyopathy causing mutation in cardiac Troponin I on the binding affinity of two known interactors of cardiac Troponin I

Annika Neethling, Jacoba Martina Mouton and Craig Kinnear

The role of the novel biomarker ST2 as a marker of left ventricular remodelling in a native African

Hypertensive Cohort

Dike Oiji, L. Lacerda, S. Lecour, M. Adeyemi Billyrose and K. Sliwa

Persistence of escape rhythm in chronically paced patients with permanent complete heart block

Andrzej Okreglicki and Luzaan Papenfus

Evaluation of inflammatory markers in hypertensive patients vs normotensive

E. Paraskevopoulou, M.Skoura, B.Geladaki, E. Kastrinelli, A. Xanthopoulos, S.Patsilinakos and P. Paraskevopoulou

Red blood cell distribution width (RDW) as a new biological marker of heart failure - correlation with brain natriuretic peptide (BNP)

E. Paraskevopoulou, A. Xanthopoulos, I. Stergiou, E. Kastrinelli, M. Skoura, H. Theofanakis, P. Paraskevopoulou and S.Patsilinakos

Mitral regurgitation in congenital submitral aneurysm (SMA): a clinical and echocardiographic perspective Anupa Patel, Ferande Peters, Hiral Matioda, Elena Libhaber, Farouk Mamdoo and Mohammed R. Essop

Morphologic assessment of the rheumatic mitral valve

Alfonso Pecoraro, Zaheera Cassimjee, Philip Herbst and Anton Doubell

HDL/Sphingosine-1-phosphate protects SAFEly: a potential role of the mitochondria in conferring cardioprotection

Sarah Pedretti, Damian Hacking, Miguel A. Frias, Richard W. James and Sandrine Lecour

GST polymorphisms and the risk of early onset coronary artery disease in young South African Indians

Alisa Phulukdaree, Sajidah Khan, Devapregasen Moodley and Anil Chuturgoon

The interaction of common polymorphisms of the lipoprotein lipase and PON1 genes with cardiovascular risk factors in the Phoenix community

Rosaley Prakaschandra, Michelle Gordon and D.P. Naidoo

The proper delivery pressure for cardioplegic solution in neonatal cardiac surgery: an investigation of biomechanical and structural properties of neonatal coronary arteries

Normunds Sikora, Aris Lacis, Vladimir Kasyanov, Elina Ligere, Valts Ozolins and Lauris Smits 
Proteomic characterisation of cardiac endothelial cell responses to TNF-Alpha and asymmetric dimethylarginine (ADMA) stimulation

Hans Strijdom, Salome Smit, Corli Westcott, Mashudu Mudau and Amanda Genis

Novel sarcomeric hypertrophy modifier proteins that interact with titin in hypertrophic cardiomyopathy Carol Todd, Jacoba M. Mouton, Johanna C. Moolman-Smook and Craig J. Kinnear

Baroreceptor sensitivity, cardiovascular responses and ECG left ventricular hypertrophy in men: the SABPA study

Lisa Uys, Leoné Malan, Johannes van Rooyen, Faans Steyn, Tjalf Ziemssen and Manja Reiman

Cardiac presentations of HIV positive patients at Charlotte Maxeke Johannesburg Academic Hospital Ahmed Ismail Vachiat, Riaz Garda, Lance Mkhwanzi, Keir McCutcheon, Thomas Kalk, Rohan Ramjee and Pravin Manga

Myocardial twist characteristics in an African chronic kidney disease population on haemodialysis before and after dialysis as measured by speckle tracking echocardiography

Anthony Yip, Saraladevi Naicker, Ferande Peters, Mduduzi Mashabane, Elena Libhaber, Nirthi Maharaj,

Samantha Govender, Hiral Matioda and Mohammed R. Essop 